\title{
Competitividad privada, costos de producción y análisis del punto de equilibrio de unidades representativas de producción porcina
}

\section{Private competitiveness, production costs and break-even analysis of representative pork production units}

\author{
Isidro Martínez Medinaa, Daniel Val Arreolaa, Rafael Tzintzun Rascóna, J osé de Jesús \\ Conejo Navab, Manuel Jaime Tena Martíneza
}

\begin{abstract}
RESUMEN
Se utilizó la Matriz de Análisis de Políticas (MAP) y el Análisis del Punto de Equilibrio (PE) para determinar la competitividad privada, la estructura de costos y el punto de equilibrio de once unidades de producción porcina (UPP). Considerando precios corrientes de mercado de 2010, las UPP L340, L234, H726, P55, P250, H52 y H120 fueron rentables y competitivas. Cada \$0.4 y \$0.9 invertidos en factores internos generaron un valor agregado de \$1, cubriendo los costos de los factores internos de producción, generando ganancia que fluctuó entre 1 y $10 \%$. El costo de producción promedio de $1 \mathrm{~kg}$ de cerdo en pie en las UPP estudiadas durante 2010 fue de $\$ 22.3$, constituido por los insumos comerciables, los factores internos y los insumos indirectamente comerciables: $86.5,6.8$ y $6.7 \%$ respectivamente, los rubros más representativos fueron: el alimento (75.9\%), las medicinas (8.1\%), la mano de obra $(5.2 \%)$ y los combustibles (1.6\% ). El costo de producción más alto se encontró en las UPP ubicadas en Huandacareo; (\$22.8) seguidas por las UPP de La Piedad (\$22.3) y Purépero (\$21.9). Las UPP utilizaron entre el 44.1 y $115.4 \%$ de sus ingresos para equiparar sus costos y alcanzar su punto de equilibrio. El tamaño no fue una condicionante de la mayor rentabilidad, la mayor competitividad privada, los menores costos de producción y el punto de equilibrio más bajo en las UPP estudiadas.
\end{abstract}

PAlabras Clave: Matriz de análisis de políticas, Punto de Equilibrio, Michoacán, Competitividad Privada, Costos de producción.

\begin{abstract}
It was used The Policy Analysis Matrix (PAM) and the Break Even Analysis (PE) to determine private competitiveness, production costs structure and break-even point of eleven pig production units (PPU). Considering current market Mexican prices of 2010, the UPP L340, L234, H726, P55, P250, H52 and H120 were profitable and competitive. Each $\$ 0.4$ and $\$ 0.9$ spent on internal factors generated an aggregate value of $\$ 1$, covering domestic factors of production costs, generating income that ranged between 1 and $10 \%$. Average production cost of $1 \mathrm{~kg}$ of live hog on the UPP studied during 2010 was $\mathbf{\$ 2 2 . 3}$; main components were tradable inputs, domestic factors and indirectly tradable inputs: 86.5, 6.8 and $6.7 \%$ respectively, most representative items were feed $(75.9 \%)$, medicines (8.1 \% ), labor $(5.2 \%)$ and fuel $(1.6 \%)$. Highest production cost was found in the UPP located in Huandacareo, (\$22.8) followed by La Piedad's UPP (\$22.3) and Purépero's (\$21.9). UPP studied required between 44.1 and $115.4 \%$ of their income to equate their costs. Larger scale was not a determinant of higher profitability, greater competitiveness, lower private production costs and smaller break-even point on the UPP studied.
\end{abstract}

KEY WORDS: Policy Analysis Matrix, Break-even point, Michoacán, Private competitiveness.

Recibido el 22 de julio de 2014. Aceptado el 17 de septiembre de 2014.

a Instituto de Investigaciones Agropecuarias y Forestales (IIAF) de la Universidad Michoacana de San Nicolás de Hidalgo (UMSNH). Tarímbaro, Michoacán. Km 9.5 Carretera Morelia-Zinapecuaro Tel: (443) 322350 Ext: 5219 y 5220. México. ricci78@hotmail.com. Correspondencia al primer autor.

b Facultad de Medicina Veterinaria y Zootecnia, UMSNH. México. 


\section{INTRODUCCIÓN}

Se han aplicado políticas neoliberales al sector porcícola: se retiró el subsidio al sorgo, incrementando los costos de producción de la carne de cerdo, no existe crédito para la actividad(1), se eliminaron los permisos previos para la importación de productos de cerdo, se redujeron los aranceles y se removieron las cuotas compensatorias(2), resultando en un incremento de las importaciones nacionales de $515.7 \%$ durante el lapso transcurrido de 1988 a 2007(3), generando un déficit de 700,000 $t$ que son importadas de EEUU y Canadá(4).

Las encuestas de rentabilidad porcina de FIRA señalaban desde 1998, que 10 unidades de producción porcina (UPP) en Michoacán mostraron indicadores de los más bajos de dichas encuestas a nivel nacional(5); Michoacán es de los estados con mayor contracción de la porcicultura en el periodo transcurrido entre 1990 y $2008^{(6)}$.

En 1995 se realizaron diversos estudios sobre la competitividad de las UPP en México, con la metodología de la Matriz de Análisis de Políticas (MAP), mismos que se publicaron en la década del 2000, señalando en general que: la competitividad y rentabilidad privada aumentó con el tamaño de las UPP, además, las 13 UPP estudiadas en aquellos años en Michoacán(7) considerando el análisis agregado con promedios ponderados, presentaron indicadores de mayor competitividad y rentabilidad privada a los encontrados en UPP de Guanajuato(8); sin embargo, se encontraron indicadores de mayor competitividad y rentabilidad privada en UPP ubicadas en Puebla(9), el Estado de México(10) y en Yucatán(11).

En un estudio de UPP productoras de lechón en el Estado de México durante 2010, resultaron con indicadores de competitividad privada positivos; su estructura de costos estuvo compuesta principalmente por el alimento con $64.97 \%$ (12). El rubro de mayor importancia de las UPP en Michoacán durante 1995 fue el

\section{INTRODUCTION}

Beginning in the late 1980s, neoliberal economic policies have been applied to the pork products sector in Mexico. Pork production costs increased as government subsidies of sorghum were removed, and credit for this activity dried up(1). The need for pre-import permits for pork products was eliminated, tariffs were reduced and compensatory quotas removed(2). In response, imports of pork products into Mexico boomed by $515.7 \%$ from 1988 to $2007(3)$, generating a 700,000 t product deficit imported from the USA and Canada(4).

Surveys of pork profitability done beginning in 1988 by the Agriculture Trust Funds (Fideicomisos Institutidos en Relación con la Agricultura - FIRA) of ten pork production units (PPU) in the State of Michoacán showed them to have the lowest indicators in these surveys on a national level(5). Michoacán's pork production sector was among those in Mexico that further contracted between 1990 and 2008(6).

In 1995, a number of studies about competitiveness in Mexico's PPU were done using the policy analysis matrix (PAM) approach. Published in the early years of this century, they generally observed that competitiveness and private profitability increased with PPU size. When considering aggregate analysis with weighted averages, 13 of the Michoacán PPUs studied in this period had higher competitiveness and private profitability indicators than PPUs in the State of Guanajuato(8). However, PPUs in Puebla(9), the State of Mexico(10) and Yucatán(11) exhibited even higher competitiveness and private profitability values.

Feed costs are the main element in the costs structure of PPUs in Mexico. A study of piglet production operations in the State of Mexico found positive private competiveness indicators, with a cost structure consisting mainly (64.97 \%) of feed(12). In 1995, the most important cost in Michoacán PPUs was feed, which accounted 
alimento, que representó el $95.9 \%(7)$. En Yucatán en 2007 el rubro de mayor importancia también fue el alimento que representó $72 \%$, con utilidad por kilogramo producido en pie de $\$ 5.22$ (13). En Guanajuato el alimento representó $71.3 \%$ del costo de producción, y la utilidad/ $\mathrm{kg}$ producido en pie fue de $\$ 1.88(14)$.

En los estudios de competitividad, rentabilidad privada y estructura de costos de la porcicultura en Michoacán y en el país no se incluyó el estudio del punto de equilibrio, siendo de gran utilidad para observar en qué momento de la producción de las UPP equipara los costos y los ingresos, sin tener pérdidas ni utilidades.

En este contexto, se plantearon como objetivos del estudio: generar información de calidad a nivel de UPP que permita impulsar la competitividad de la porcicultura en Michoacán, elaborar una herramienta para desarrollar un modelo atendiendo a la metodología de la MAP; determinar la competitividad privada y estructura de costos de producción de 11 UPP con la metodología de la MAP, además de realizar un análisis del punto de equilibrio de cada UPP.

\section{MATERIALES Y MÉTODOS}

La Matriz de Análisis de Políticas (MAP). Es el método vigente para dar seguimiento a las políticas agropecuarias en el contexto actual de apertura comercial: producto de dos identidades de contabilidad, una que define la rentabilidad como la diferencia entre ingresos y costos, y la otra que mide los efectos de las divergencias (distorsiones de políticas y fallas de mercado), considerando las diferencias entre los parámetros observados y los que permanecerían si se removieran las divergencias. Mediante esta Matriz se pueden medir las transferencias ocasionadas por los efectos de política que actúan sobre el sistema, así como la eficiencia económica del mismo. La utilidad se define como la diferencia (total o unitaria) entre los ingresos y los costos de producción, definición que genera la primera identidad de la matriz de contabilidad. En la MAP, la rentabilidad se mide horizontalmente for $95.9 \%(7)$. Feed was also the most important heading in PPUs in Yucatan in 2007, representing $72 \%$ of costs, with a $\$ 5.22$ profit per kilogram produced(13). This is very near the $71.3 \%$ feed cost accounted for in production costs in PPUs in the state of Guanajuato, with a \$1.88 profit/kilogram produced(14).

Not any of the pork production competitiveness, private profit and costs structure studies done in Michoacán, or Mexico, has included breakeven point (BEP) analysis. This can be extremely useful in determining the moment when PPU production balances costs and income, without generating losses or yields.

The present study objective was to generate quality data at the PPU level for use in studies that promote competitiveness in Michoacán's pork production sector. The PAM methodology was used to build a model to analyze private competitiveness and production costs structure in eleven PPUs, and a break-even point analysis run for each unit.

\section{MATERIALS AND METHODS}

\section{Policy Analysis Matrix (PAM)}

This is currently the most widely used method for analyzing agricultural policy in the present context of opening markets. It is generated from two accounting identities, one defining profitability as the difference between income and costs, and the other measuring the effects of divergences (political and market failure distortions). The differences are then considered between observed parameters and those that remain if the divergences were removed. The PAM can measure transferences caused by policy acting on the system, and the economic efficiency of the system itself. Profit is defined as the difference (total or unitary) between income and production costs; this generates the first identity in the accounting matrix. Profit is calculated by subtracting the costs shown in the two center columns from the income shown in the left column; therefore, each column entry 
entre las columnas de la matriz. La utilidad se calcula mediante la sustracción de los costos, dados en las dos columnas del centro, a partir de los ingresos indicados en la columna de la izquierda. Por lo tanto, cada una de las entradas de la columna es un componente de la identidad de rentabilidad ingresos-costos=utilidad. Cada MAP contiene dos columnas, una para insumos comerciables y la otra para factores domésticos (Cuadro 1).

Precios privados. En la construcción de la MAP se utilizaron precios de insumos y productos del año 2010 tomados de las asociaciones locales de La Piedad, Purépero y Huandacareo y el Sistema Nacional de Información e Integración de Mercados (SNIIM) la Secretaría de Economía.

Utilidad privada (D). Se calcula A-B-C=D, (Cuadro 1), el término privado se refiere a que considera los precios corrientes de mercado, pagados y cobrados por los productores en el sistema, los precios privados incorporan los costos y valores económicos más el efecto de las políticas y las fallas de mercado, la primera fila de la MAP considera únicamente precios privados, el estudio de la rentabilidad privada muestra la competitividad del sistema agropecuario dadas las tecnologías utilizadas, valores de productos, costos de insumos y transferencias de política. El costo de capital que se define como el retorno antes de impuestos que los poseedores de capital requieren para mantener su inversión en el sistema, está incluido en los costos privados (C), por lo tanto, las utilidades (D) son utilidades is a component of the profitability identity (income-costs $=$ profit). Every PAM has two columns: one for marketable inputs and another for internal factors (Table 1).

Private prices. Building of the present PAM was based on input and product costs from 2010 taken from PPUs in the municipalities of La Piedad, Purépero and Huandacareo in Michoacán, as well as the National System of Market Data and Integration (Sistema Nacional de Información e Integración de Mercados SNIIM) of the Ministry of the Economy.

Private profit (D). This is calculated as $A-B-C=D$ (Table 1). "Private" refers to the fact that it considers market prices paid and charged by system producers. Private prices incorporate the economic costs and values plus the effect of policies and market failures. The first row of the PAM includes only private costs. Study of private profitability shows agricultural system competitiveness given the technologies utilized, product value, input costs and policy transfers. Capital cost is defined as the pre-tax yield that those holding the capital require to maintain their investment in the system. This is included in private costs $(C)$, and, therefore, (D) is excess profits, that is, the profits that exceed a producers' normal return on capital.

A negative profit $(D<0)$ means producers are receiving a below normal rate of return, and it can be expected that they leave the activity unless it increases at least to a normal level $(D=0)$. A positive private profits value $(D>0)$ indicates higher than normal returns that should

Cuadro 1. La Matriz de análisis de políticas de Monke y Pearson (1989)

Table 1. Policy Analysis Matrix (PAM) (Monke and Pearson, 1989)

\begin{tabular}{lcccc}
\hline & & \multicolumn{2}{c}{ Costs } & \\
\cline { 2 - 5 } & Income & Marketable Inputs & Internal Factors & Profit \\
\hline Private prices & $\mathrm{A}$ & $\mathrm{B}$ & $\mathrm{C}$ & $\mathrm{D}$ \\
Social prices & $\mathrm{E}$ & $\mathrm{F}$ & $\mathrm{G}$ & $\mathrm{H}$ \\
Divergences & $\mathrm{I}$ & $\mathrm{J}$ & $\mathrm{K}$ & $\mathrm{L}$ \\
\hline
\end{tabular}


en exceso o que superan el retorno normal de capital para los productores.

Si la utilidad es negativa $(D<0)$, los productores están recibiendo una tasa de retorno por debajo de la normal, se esperaría su salida de la actividad a menos que se incremente al menos al nivel normal $(D=0)$. Si la utilidad privada es positiva $(D>0)$ indica que existen retornos por encima de los normales y que llevaría a una expansión del sistema a menos que el área no pueda ser expandida o existan otras actividades más rentables en términos privados(15).

La relación de costo privado (RCP). Se utiliza para comparar sistemas que generan diferentes productos; es la relación de costos de los factores domésticos $(C)$ al valor agregado en precios privados $(A-B) ; R C P=C /(A-B)$. La $R C P$ es un indicador de competitividad. Si $0<R C P \leq 1$, el sistema es rentable y competitivo(15).

La relación de rentabilidad privada (RRP). Es el cociente de las ganancias privadas (D) entre el costo privado de producción $(B+C)(15)$.

Valor agregado en precios privados (VA). Es la contribución de la actividad al ingreso del sector agropecuario, o bien el monto del ingreso total de la UPP utilizado en pagar mano de obra, créditos, agua, electricidad y administración. Es el pago o remuneración de los factores internos de producción, refleja el efecto de la producción hacia el interior del sector, se calcula $A-B=$ $(\$ V A),(V A \%)=(A-B) / A^{(15)}$.

El análisis del punto de equilibrio (PE). Es el punto de actividad que existe cuando los costos y los ingresos se equiparan; en este punto la empresa no experimenta pérdidas ni tampoco utilidades. Punto de equilibrio en ventas (PE) \$=costos fijos* 1/1-costos variables/ventas totales. Punto de equilibrio en porcentaje (PE) $\%=$ costos fijos/ventas totales-costos variables*100. Punto de equilibrio en unidades producidas (PE)U=costos fijos*unidades producidas/ventas totales-costos variables $(16,17)$. cause the system to expand, unless expansion is no longer possible in the area or more profitable activities (in private terms) exist(15).

Private cost ratio (PCR). Used to compare systems generating different products, the PCR is the ratio of internal factor costs $(C)$ to the value added in private prices $(A-B) ; P C R=C$ l $(A-B)$. It is a competitiveness indicator; if $0<P C R \leq 1$, a system is profitable and competitive(15).

Private profitability ratio (PPR). This is calculated as the quotient of the private profit (D) and the private production cost $(B+C)(15)$.

Value added in private prices (VA). This is the contribution of the activity to agricultural sector income, or the total income of a PPU used to pay labor, credit, water, electricity and administration costs. It is payment or remuneration of internal production factors as reflected in the effect of production on the internal sector, and is calculated as $A-B=(\$ V A)$, $(\mathrm{VA} \%)=(\mathrm{A}-\mathrm{B}) / \mathrm{A}^{(15)}$.

Break-even point analysis (BEP)

The break-even point in an activity is reached when costs and income are in balance. At this point, a company has no losses and no profit; Sales BEP $\$=$ fixed costs*1/1-variable costs/ total sales. Percentage BEP \%= fixed costs/ total sales - variable costs*100. Units produced BEP $U=$ fixed costs* unit produced/total sales variable costs $(16,17)$.

Pork production units. Eleven PPUs were studied. All are located in the three municipalities ( $\mathrm{La}$ Piedad, Huandacareo and Purépero) accounting for the majority ( $41 \%$ ) of Michoacán's pork production(18) (Table 2). Three inclusion criteria were used in PPU selection: 1) willingness of the principal decision maker to participate in the study; 2) the producer had been in the sector for a long period; 3) the PPU engages in pork production as a full-time activity. To collect data on inputs and products during 2010, PPU productive and reproductive records were 
UPP consideradas en el estudio. Se estudiaron 11 UPP ubicadas en los tres municipios de mayor producción de carne de cerdo; La Piedad, Huandacareo y Purépero, municipios que en conjunto produjeron el $41 \%$ de la carne de cerdo en Michoacán(18), (Cuadro 2). Los criterios de inclusión de las UPP en el estudio fueron: la disposición del tomador de decisiones a participar en el estudio, ser una UPP productora de cerdo en pie con el mayor tiempo en funcionamiento y que se dedicaran a la actividad tiempo completo. Se revisaron registros productivos y reproductivos de las UPP, además de realizar un cuestionario a los tomadores de decisiones de las mismas, obteniendo información de insumos y productos utilizados durante 2010.

\section{RESULTADOS}

Competitividad privada. De las 11 UPP estudiadas, H52, H120, H726, L234, L340, P55 y P250 resultaron ser rentables y competitivas considerando precios privados de 2010 (Cuadros $3,4,5)$.

La UPP más rentable y competitiva del estudio fue L340; sin ser la de mayor escala sustenta su competitividad con el costo de producción
Cuadro 2. Ubicación, capacidad instalada y clave de las unidades de producción (UPP) estudiadas

Table 2. Location, installed capacity and keys of studied pork production units (PPU)

\begin{tabular}{lccc}
\hline PPU & Location & Females $(\mathrm{n})$ & Name \\
\hline 1 & Huandacareo & 726 & $\mathrm{H} 726$ \\
2 & Huandacareo & 120 & $\mathrm{H} 120$ \\
3 & Huandacareo & 52 & $\mathrm{H} 52$ \\
4 & Huandacareo & 179 & $\mathrm{H} 179$ \\
5 & La Piedad & 150 & $\mathrm{~L} 150$ \\
6 & La Piedad & 234 & $\mathrm{~L} 234$ \\
7 & La Piedad & 250 & $\mathrm{~L} 250$ \\
8 & La Piedad & 340 & $\mathrm{~L} 340$ \\
9 & Purépero & 55 & $\mathrm{P} 55$ \\
10 & Purépero & 160 & $\mathrm{P} 160$ \\
11 & Purépero & 250 & $\mathrm{P} 250$ \\
\hline
\end{tabular}

reviewed, and a questionnaire was applied to the decision makers.

\section{RESULTS}

Private competitiveness. Of the eleven studied PPU, seven (H52, H120, H726, L234, L340, P55 and P250) were profitable and competitive based on 2010 private prices (Table 3, 4, 5).

Cuadro 3. Indicadores de competitividad privada y punto de equilibrio de las unidades de producción (PPU) estudiadas en Huandacareo, Michoacán

Table 3. Private competitiveness indicators and break-even point for studied pork production units (PPU) in Huandacareo, Michoacán

\begin{tabular}{lllll}
\hline & \multicolumn{4}{c}{ PPU } \\
\cline { 2 - 5 } & \multicolumn{1}{c}{ H726 } & H120 & H52 & \multicolumn{1}{c}{179} \\
\hline Profit, \$ & $1 ' 547,379$ & 42,514 & 35,712 & $-150,916$ \\
Value added, $\$$ & 816,980 & 366,775 & 175,811 & $-640,547$ \\
PPR, \% & 6 & 1 & 2 & -3 \\
PCR & 0.5 & 0.9 & 0.8 & 3.2 \\
BEP, \% & 77.6 & 109.8 & 115.4 & -245.0 \\
BEP, units & 10,068 & 2,154 & $2,073,511$ & $-10 ' 797,063$ \\
BEP, $\$$ & $21^{\prime} 748,930$ & $4{ }^{\prime} 653,861$ & 960 & $-4,595,299$ \\
\hline
\end{tabular}

Source: generated by authors from pork producer data and current 2010 market prices.

$\mathrm{PPR}=$ private profitability ratio; $\mathrm{PCR}=$ private cost ratio; $\mathrm{BEP}=$ break-even point. 
COSTOS DE PRODUCCIÓN EN UNIDADES REPRESENTATIVAS DE PRODUCCIÓN PORCINA

Cuadro 4. Indicadores de competitividad privada y punto de equilibrio de las unidades de producción (PPU) estudiadas en La Piedad, Michoacán

Table 4. Private competitiveness indicators and break-even point for studied pork production units (PPU) in La Piedad, Michoacán

\begin{tabular}{lllll}
\hline & \multicolumn{4}{c}{ PPU } \\
\cline { 2 - 5 } & \multicolumn{1}{c}{ L150 } & \multicolumn{1}{c}{ L234 } & \multicolumn{1}{c}{ L250 } & \multicolumn{1}{c}{ L340 } \\
\hline Profit, \$ & $-943,891$ & 569,394 & $-409,593$ & 1 '941,382 \\
Value added, \$ & $-472,760$ & 1 '108,400 & $-539,506$ & 1 '801,560 \\
PPR, \% & -16 & 8 & -4 & 12 \\
PCR & -1 & 0.49 & 1.76 & 0.3 \\
BEP, \% & 556.9 & 60.5 & 173.4 & 28.3 \\
BEP, units & 13,699 & 2,035 & 8,672 & 1,399 \\
BEP, \$ & $29 ' 595,428$ & 4 '395,953 & 18 '732,689 & 3'022,352 \\
\hline
\end{tabular}

Source: generated by authors from pork producer data and current 2010 market prices.

$\mathrm{PPR}=$ private profitability ratio; $\mathrm{PCR}=$ private cost ratio; $\mathrm{BEP}=$ break-even point.

Cuadro 5. Indicadores de competitividad privada y punto de equilibrio de las unidades de producción (PPU) estudiadas en Purépero, Michoacán

Table 5. Private competitiveness indicators and break-even point for studied pork production units (PPU) in Purépero, Michoacán

\begin{tabular}{llll}
\hline & \multicolumn{3}{c}{ PPU } \\
\cline { 2 - 4 } & \multicolumn{1}{c}{ P55 } & P160 & P250 \\
\hline Profit, \$ & $-78,303$ & 88,493 & 381,244 \\
Value added & $-262,383$ & $-2 ' 472,928$ & 550,942 \\
PPR, \% & 5 & -2 & 3 \\
PCR & 0.7 & 1.67 & 0.31 \\
BEP, \% & 94.1 & 188.2 & 86.7 \\
BEP, units & 732 & 3,285 & 3,375 \\
BEP, \$ & $1 ' 538,747$ & $7 ' 110,313$ & 7 '303,653 \\
\hline
\end{tabular}

Source: generated by authors from pork producer data and current 2010 market prices.

$\mathrm{PPR}=$ private profitability ratio; $\mathrm{PCR}=$ private cost ratio; $\mathrm{BEP}=$ break-even point .

de $\$ 19.7$ y el punto de equilibrio más bajo $28.3 \%$. Esto permitió que obtuviera una utilidad por kilogramo de cerdo vendido de $\$ 4.9$, mismo que se reflejó en su RCP de 0.3 y su RRP de $12 \%$; también fue la unidad que en mayor medida remuneró a los factores de producción: electricidad, mano de obra y administración $\$ 1,801,56$.
The most profitable PPU was L340. It did not have the largest scale, but its competitiveness was supported by a $\$ 19.7$ production cost and a $28.3 \%$ BEP, the lowest of the sampled PPUs. These variables allowed it to achieve a $\$ 4.9$ profit/kilogram pork, which was reflected in its PCR (0.3) and PPR ( $12 \%$ ). It was also the PPU that most highly remunerated production 
Estructura de costos. El costo de producción promedio general en las UPP fue de $\$ 22.3$, del cual $\$ 19.3$ (86.5 \%) fueron insumos comerciables; de este rubro $\$ 17.0$ (72.3\%) lo representó la alimentación, \$1.8 (8.1\%) lo representaron los medicamentos, los combustibles representaron $\$ 0.4(1.6 \%)$, los factores internos representaron $\$ 1.5(6.8 \%)$ y los insumos indirectamente comerciables $\$ 1.5(6.7 \%)$. El costo de producción más alto se encontró en las UPP de Huandacareo ( $\$ 22.8)$ seguidas por las UPP de La Piedad (\$22.3) y Purépero (\$21.9). Individualmente, en orden del mayor al menor costo de producción, fueron las unidades L150 (\$26.4), H179 (\$25.9), P160 (\$23.1), L250 (\$22.8), H52 (\$22.2), H120 (\$22), P55 (\$21.4), factors: \$1801.56 (electricity, labor and administration).

Costs structure. Average general production cost in the studied PPU was $\$ 22.3$. Of this total, marketable inputs accounted for $\$ 19.3(86.5 \%)$, including \$17.0 (72.3\%) for feed, \$1.8 (8.1\%) for medication, and $\$ 0.4$ (1.6\%) for fuel. Internal factors accounted for $\$ 1.5(6.8 \%)$ and indirect marketable inputs for $\$ 1.5(6.7 \%)$. The highest production cost was identified in the Huandacareo PPUs (\$22.8), followed by those in La Piedad (\$22.3) and Purépero (\$21.9). Production cost was lowest in L340 (\$19.7), followed by L234 (\$20.4), H726 (\$21.1), P250 (\$21.3), P55 (\$21.4), H120 (\$22), H52

Cuadro 6. Cantidades promedio de insumos comerciables, factores internos e insumos indirectamente comerciables utilizados en las PPU de Huandacareo, Michoacán estudiadas durante el 2010 (\$)

Table 6. Averages for marketable inputs, internal factors and indirect marketable inputs used by the studied PPU in Huandacareo, Michoacán in 2010 (\$)

\begin{tabular}{lrrrrr}
\hline & \multicolumn{4}{c}{$\mathrm{PPU}$} & \\
\cline { 2 - 5 } Technology used & $\mathrm{H} 726$ & $\mathrm{H} 120$ & $\mathrm{H} 52$ & $\mathrm{H} 179$ & Percentage \\
\hline Marketable inputs: & 18.4 & 18.8 & 18.8 & 23.9 & 86.8 \\
Feed & 15.3 & 15.5 & 15.6 & 18.7 & 71.5 \\
Medicine & 2.6 & 2.6 & 2.4 & 3.4 & 12.0 \\
Disinfectants & 0.1 & 0.1 & 0.1 & 0.1 & 0.4 \\
Misc. materials & 0.0 & 0.0 & 0.0 & 0.7 & 0.1 \\
Fuel & 0.4 & 0.6 & 0.7 & 0.4 & 3.0 \\
Internal factors: & 1.0 & 1.7 & 2.0 & 1.6 & 6.4 \\
Labor & 0.8 & 1.4 & 1.7 & 1.2 & 5.3 \\
Credit & 0.0 & 0.0 & 0.0 & 0.0 & 0.0 \\
Electricity & 0.2 & 0.1 & 0.1 & 0.3 & 0.6 \\
Water & 0.0 & 0.1 & 0.1 & 0.0 & 0.3 \\
Telephone & 0.0 & 0.1 & 0.1 & 0.1 & 0.2 \\
Internet & 0.0 & 0.0 & 0.0 & 0.0 & 0.2 \\
Others & 0.0 & 0.0 & 0.0 & 0.0 & 0.0 \\
Indirect marketable: & 1.7 & 2.0 & 1.4 & 1.6 & 6.8 \\
Grow pigs & 0.1 & 0.5 & 0.0 & 0.2 & 0.2 \\
Vehicles & 0.0 & 0.0 & 0.0 & 0.0 & 0.0 \\
Installations & 0.6 & 0.5 & 0.4 & 0.4 & 2.4 \\
Misc. Expenses & 1.0 & 1.0 & 1.0 & 1.0 & 4.2 \\
Pork production costs / kg & 21.1 & 22.0 & 22.2 & 25.9 & \\
\hline
\end{tabular}


P250 (\$21.3), H726 (\$21.1), L234 (\$20.4) y L340 (\$19.7). (Cuadros 7, 8 y 9).

La utilidad por kilogramo producido durante el año 2010 fue en promedio de $\$ 0.5$; en las UPP de Huandacareo $-\$ 0.3$, en La Piedad de $\$ 1.4$ y en Purépero de $\$ 0.5$.

Punto de Equilibrio. Las UPP estudiadas utilizaron entre el $28.3 \%$ y el $556.9 \%$ de sus ingresos para equiparar sus costos, en orden de menor a mayor punto de equilibrio las UPP: L340, L234, H726, P250, P55, H120, H52, L250, P160, H179 y L150. Encontrándose que el tamaño de las UPP que tuvieron un punto de equilibrio más manejable, que requirieron de menores ingresos para cubrir sus costos, se encontró entre 234 y
(\$22.2), L250 (\$22.8), P160 (\$23.1), H179 (\$25.9), and L150 (\$26.4) (Tables 6, 7, 8).

Average overall profit $/ \mathrm{kg}$ produced in 2010 was $\$ 0.5$, with $\$ 1.4$ in the La Piedad PPUs, $\$ 0.5$ in the Purépero PPUs, and $-\$ 0.3$ in the Huandacareo PPUs.

Break-even point. The amount of PPU income used to balance costs varied from 28.3 to $556.9 \%$. The lowest BEP was at L340, followed by L234, H726, P250, P55, H120, H52, L250, P160, H179 and finally L150. Small and semimechanized PPUs (i.e. 234 to 340 sows) had the most manageable BEP and required less of their income to cover costs (Tables 3, 4, 5).

Cuadro 7. Cantidades promedio de insumos comerciables, factores internos e insumos indirectamente comerciables utilizados en las PPU de La Piedad, Michoacán estudiadas durante el 2010 (\$)

Table 7. Averages for marketable inputs, internal factors and indirect marketable inputs used by the studied PPU in La Piedad, Michoacán in 2010 (\$)

\begin{tabular}{lrrrrr}
\hline & \multicolumn{3}{c}{ PPU } & Percentage \\
\cline { 2 - 5 } Technology used & L150 & L250 & L234 & L340 & 86.6 \\
\hline Marketable inputs: & 22.7 & 19.7 & 17.6 & 15.4 & 79.0 \\
Feed & 21.1 & 18.6 & 16.6 & 14.2 & 4.7 \\
Medicine & 1.2 & 1.0 & 0.9 & 1.1 & 0.2 \\
Disinfectants & 0.1 & 0.0 & 0.0 & 0.0 & 0.1 \\
Misc. Materials & 0.0 & 0.0 & 0.0 & 0.0 & 0.6 \\
Fuel & 0.3 & 0.1 & 0.1 & 0.1 & 7.0 \\
Internal factors: & 2.1 & 1.9 & 1.5 & 1.2 & 5.0 \\
Labor & 1.3 & 1.2 & 1.2 & 0.9 & 0.0 \\
Credit & 0.0 & 0.0 & 0.0 & 0.0 & 2.0 \\
Electricity & 0.8 & 0.7 & 0.3 & 0.3 & 0.0 \\
Water & 0.0 & 0.0 & 0.0 & 0.0 & 0.0 \\
Telephone & 0.0 & 0.0 & 0.0 & 0.0 & 0.0 \\
Internet & 0.0 & 0.0 & 0.0 & 0.0 & 0.0 \\
Others & 0.0 & 0.0 & 0.0 & 0.0 & 6.0 \\
Indirect marketable: & 1.6 & 1.2 & 1.3 & 1.5 & 2.0 \\
Growth pigs & 0.5 & 0.2 & 0.3 & 0.8 & 0.0 \\
Vehicles & 0.0 & 0.0 & 0.0 & 0.0 & 0.0 \\
Installations & 0.0 & 0.0 & 0.0 & 0.0 & 4.0 \\
Misc. expenses & 1.1 & 1.0 & 1.0 & 0.7 & \\
Pork production costs / $\mathrm{kg}$ & 26.4 & 22.8 & 20.4 & 19.7 & \\
\hline
\end{tabular}


Cuadro 8. Cantidades promedio de insumos comerciables, factores internos e insumos indirectamente comerciables utilizados en las UPP de Purépero, Michoacán estudiadas durante 2010 (\$)

Table 8. Averages for marketable inputs, internal factors and indirect marketable inputs used by the studied PPUs in Purépero, Michoacán in 2010 (\$)

\begin{tabular}{|c|c|c|c|c|}
\hline \multirow[b]{2}{*}{ Technology used } & \multicolumn{3}{|c|}{ PPU } & \multirow[b]{2}{*}{ Percentage } \\
\hline & P55 & P160 & P250 & \\
\hline Marketable inputs: & 17.3 & 20.1 & 19.6 & 86.6 \\
\hline Feed & 14.3 & 18.1 & 18.5 & 77.3 \\
\hline Medicine & 2.3 & 1.7 & 1.0 & 7.6 \\
\hline Disinfectants & 0.1 & 0.1 & 0.0 & 0.4 \\
\hline Misc. materials & 0.0 & 0.0 & 0.0 & 0.0 \\
\hline Fuel & 0.5 & 0.2 & 0.1 & 1.3 \\
\hline Internal factors: & 2.4 & 1.3 & 0.4 & 6.2 \\
\hline Labor & 2.0 & 1.1 & 0.4 & 5.0 \\
\hline Credit & 0.0 & 0.0 & 0.0 & 0.0 \\
\hline Electricity & 0.4 & 0.1 & 0.0 & 0.7 \\
\hline Water & 0.0 & 0.0 & 0.0 & 0.1 \\
\hline Telephone & 0.0 & 0.0 & 0.0 & 0.4 \\
\hline Internet & 0.0 & 0.0 & 0.0 & 0.0 \\
\hline Others & 0.0 & 0.0 & 0.0 & 0.0 \\
\hline Indirect marketable: & 1.7 & 1.8 & 1.3 & 7.2 \\
\hline Growth pigs & 0.0 & 0.0 & 0.0 & 0.0 \\
\hline Vehicles & 0.0 & 0.0 & 0.0 & 0.0 \\
\hline Installations & 0.9 & 0.7 & 0.3 & 2.5 \\
\hline Misc. expenses & 0.8 & 1.1 & 1.0 & 4.7 \\
\hline Pork production costs / kg & 21.4 & 23.1 & 21.3 & \\
\hline
\end{tabular}

340 vientres, según el tamaño clasificadas como pequeñas y semitecnificadas. (Cuadros 3, 4, 5).

\section{DISCUSIÓN}

Considerando el análisis agregado utilizando promedios ponderados las UPP estudiadas durante 2010 mostraron indicadores de mayor competitividad privada a los encontrados en Michoacán en 1995, Guanajuato en 1995, Puebla en $1995(7,8,9)$ y menores a los encontrados en el estado de México en 2008, Yucatán en 1995, y las UPP productoras de lechón estudiadas en $2010(10,11,12)$.

Al comparar los indicadores de las UPP estudiadas en 2010 con las analizadas

\section{DISCUSSION}

The aggregated analysis using weighted averages showed that in 2010 the studied PPUs had higher private competitiveness indicator values than those in Michoacán, Guanajuato and Puebla in $1995(7,8,9)$. However, these values were still lower than values reported for PPUs in Mexico in 2008, Yucatan in 1995, and pig production operations in $2010(10,11,12)$.

Compared to the 1995 results(7), the 2010 results show small PPUs (100-300) to be more numerous in the present study. Moreover, there profitability and competitiveness were higher $15 \mathrm{yr}$ later, nearing those of the medium-sized PPUs (301 to 600) in 1995. Medium and large 
inicialmente $(7)$ se aprecia que el segmento de las UPP pequeñas (100-300) es más numeroso en el presente estudio, su rentabilidad y competitividad son más altas acercándose al segmento de medianas (301-600) del estudio que se llevó a cabo en Michoacán en 1995, en 2010 se encontraron UPP representantes del segmento medianas y grandes (601-1000) que fueron más rentables y más competitivas a las estudiadas anteriormente.

Son múltiples las variables que afectaron la competitividad privada de las UPP; se observó que la estructura de costos es distinta en relación al estudio anterior realizado en Michoacán, siendo mayores (6.4 \%) los insumos comerciables: erogaron una mayor cantidad de recursos en la compra de medicinas, vacunas, combustibles, desinfectantes y materiales diversos; también fueron mayores (1.76 \%) los factores internos: la mano de obra, los créditos, la energía eléctrica, los gastos de administración y gastos diversos; los insumos indirectamente comerciables: recursos utilizados en pie de cría, vehículos, equipamiento e instalaciones fueron menores (47.31\%); el rubro del alimento fue $23 \%$ menor. Las UPP estudiadas en 2010 mostraron una mayor competitividad a las estudiadas anteriormente en Michoacán(7).

En relación con las UPP productoras de lechón estudiadas el mismo año que el presente estudio(12), las UPP presentaron insumos comerciables $15 \%$ más altos, factores internos $20 \%$ más bajos, insumos indirectamente comerciables $5 \%$ más altos y el alimento $7.3 \%$ más bajo.

La utilidad por kilogramo producido en las UPP de Yucatán y Guanajuato en 2007 fue 10.77 y 3.76 veces mayor al encontrado en las UPP en Michoacán durante 2010. Esto se debió a las diferencias en los costos de producción. En cuanto a la porcicultura en Guanajuato, cuenta con la ventaja de ser el tercer productor de sorgo a nivel nacional, del cual, la tercera parte se destina a la porcicultura. Por otra parte, Yucatán cuenta con ventajas de gran demanda
PPUs (601 to 1000) were even more profitable and competitive in 2010 than the same sectors in 1995.

Multiple factors affected PPU private competitiveness. Costs structure in 2010 differed from the previous data from Michoacán. Marketable inputs costs were higher $(6.4 \%)$ than $15 \mathrm{yr}$ before, with more resources used to buy medicine, vaccines, fuel, disinfectants and miscellaneous materials. Internal factor costs were also higher ( $1.76 \%$ ), due largely to labor, credit, electricity, administrative expenses and miscellaneous expenses. In contrast, indirect marketable inputs (resources for grow pigs, vehicles, equipment and installations) were less $(47.31 \%)$ than previously reported, as were feed costs (23\%). Generally, the Michoacán PPUs studied in 2010 were more competitive than those studied in 1995(7).

When compared to piglet production operations data from 2010(12), the Michoacán PPUs had $15 \%$ higher marketable inputs costs, $20 \%$ lower internal factor costs, $5 \%$ lower indirect marketable inputs costs, and $7.3 \%$ lower feed costs.

Profit per kilogram produced in PPUs in Yucatán in 2007 was 10.77 times than that in Michoacán in 2010, and in PPUs in Guanajuato it was 3.76 times greater. This difference was due to discrepancies in production costs. For example, Guanajuato is the third largest sorghum producer nationally, and a third of its production goes to pork production. Yucatán has very high internal demand and supplies a highly profitable export market niche that allows prices there to be kept higher than the national average(19).

\section{CONCLUSIONS AND IMPLICATIONS}

Production unit size was not a condition for efficient PPU operation in Michoacán in 2010. In adverse scenarios, PPUs such as L340 and L234 could be those with the greatest capacity to adapt to market movements because their break-even point and production costs are low. 
en el mercado interno, además de atender un nicho de mercado de exportación muy rentable que le permite ofrecer precios mayores al promedio nacional(19).

\section{CONCLUSIONES E IMPLICACIONES}

El tamaño no fue una condición para el funcionamiento eficiente de una UPP en Michoacán durante 2010; frente a escenarios adversos, podrían ser las UPP como L340 y L234 las que mayor capacidad tengan para adaptarse a los movimientos del mercado debido a su punto de equilibrio y costos de producción más bajos. El punto de equilibrio mostró ser más riguroso como indicador, que los indicadores de la MAP, algunas UPP como H120 y H52, fueron rentables y competitivas considerando la RRP y la RCP, tuvieron un PE que excedía en $100 \%$ de sus ingresos; esto se debe a que el cálculo del punto de equilibrio se realiza por producto, y en el mismo, sólo se toma en cuenta a los cerdos producidos de peso de mercado y no a los cerdos de desecho, que también se consideran en la MAP. El análisis del punto de equilibrio robusteció el panorama de la MAP, mostrando la cantidad precisa de cerdos de peso de mercado, porcentaje y ventas que requiere producir cada UPP para equiparar sus costos sin pérdidas ni utilidades.

\section{LITERATURA CITADA}

1. Moral-Barrera LED, Ramírez-Gómez BP, Muñoz-J umilla AR. Crecimiento regional de la producción de carne de cerdo en México, 1980-2005. Análisis Económico 2008; XXIII:271290.

2. Sagarnaga-Villegas LM. Panorama económico de granjas porcinas representativas del estado de Guanajuato 20022009. lera ed. Universidad Autónoma Chapingo, México. Plaza y Valdés Editores; 2006.

3. Pérez-Vera FC, García-Mata R, Martínez DMA, Mora FJS, Vaquera HH, González EA. Efecto de las importaciones de carne de porcino en el mercado mexicano, 1961-2007. Rev Mex Cienc Pecu 2010;1(2): 115-126.

4. Vargas-Palma. Oportunidades y retos en la porcicultura mexicana. El Economista. 2014. http://eleconomista.com.mx/ columnas/agro-negocios/2014/04/23/oportunidades-retosporcicultura-mexicana-ii. Consultado 23 abril, 2014.
Break-even point is clearly a more rigorous indicator than the PAM indicators. For example, PPUs such as $\mathrm{H} 120$ and $\mathrm{H} 52$ were profitable and competitive based on their PPR and PCR, but their BEP exceeded $100 \%$ of their income. This is because the BEP is calculated by product, considering only market weight pigs produced and not waste pigs, which are included in the PAM. In fact, the BEP analysis supported the PAM results by indicating the exact number of market weight pigs, percentage and sales required per PPU to balance costs without losses or profits.

End of english version

5. Tinoco-J aramillo JL. La porcicultura mexicana y el tratado de libre comercio de América del Norte. Universidad Nacional Autónoma de México; México. 2004.

6. Bobadilla-Soto E, Espinoza A, Martínez F. Dinámica de la producción porcina en México de 1980 a 2008. Rev Mex Cienc Pecu 2010; 1:251-268.

7. Barrón-Aguilar JF, García-Mata R, Mora-Flores JS, LópezDíaz S, Pró-Martínez A, García-Sánchez RC. Competitividad y efectos de política económica en la producción de cerdo en pie de 13 granjas porcícolas en el estado de Michoacán, 1995. Agrociencia 2000;34:369-377.

8. Sosa MM, García MR, Omaña SJM, López LE. Rentabilidad de doce granjas porcícolas en la región noroeste de Guanajuato en 1995. Agrociencia 2000;(34):107-113.

9. García-Sánchez RB, Matus-Gardea JA, García-Mata R, Omaña-Silvestre M, García-Delgado G. Competitividad de nueve granjas porcícolas en Tehuacán, Puebla, en 1995. Agrociencia 2000;34:99-106.

10. Hernández-Martínez J, Rebollar-Rebollar S, Rojo-Rubio R, García-Salazar JA, Guzmán-Soria E, Martínez-Tinajero JJ, Díaz-Carreño, MA. Rentabilidad privada de las granjas porcinas en el sur del Estado de México. Universidad y Ciencia. 2008;24(2): 117-124.

11. Magaña-Magaña MA, Matus-Gardea JA, García-Mata R, Santiago-Cruz MJ, Martínez-Damián MA, Martínez-Garza A. Rentabilidad y efectos de política económica en la producción de carne de cerdo en Yucatán. Agrociencia 2002;36:737747.

12. Bobadilla-Soto EE, Espinoza-Ortega A, Martínez-Castañeda FE. Competitividad y rentabilidad en granjas porcinas productoras de lechón. Rev Mex Cienc Pecu 2013;4(1):87-92.

13. Nava-Navarrete JJ. Porcicultura de ciclo completo del estado de Yucatán [tesis Maestría]. México: Universidad Nacional Autónoma de México; 2007.

14. Osorio Herrera ME. Impacto del TLCAN en empresas porcícolas de ciclo completo en el estado de Guanajuato [tesis Maestría], México: Universidad Nacional Autónoma de México; 2007. 
15. Monke E, Pearson S. The policy analysis matrix for agricultural development. Ithaca and London: Cornell Univ Press; 1989.

16. Mbaso M, Kamwana B. Comparative analysis of profitability among feeder-pig, pig-finishing, and farrow-to-finish production systems under the Smallholder Improvement Management System in Ntcheu District of Central Malawi. Livest Res Rural Develop 2013;25(10): http://www.Irrd.org/ Irrd25/10/mbas25175.htm. Accessed Jan 13, 2014.

17. Phiri RE. Determination of piggery business profitability in Balaka District in Malawi. Livest Res Rural Develop
2012; 24(147). http://www.Irrd.org/lrrd24/8/phir24147.htm. Accessed Dec 11, 2013.

18. SIAP. Servicio de Información Agroalimentaria y Pesquera Estadistica Agropecuaria. Anuarios estadísticos de la producción pecuaria, porcinos http//www.siap.gob.mx/ index. php?option=com_wrapper\&view=wrapper\&l temid=369. Consultado 5 marzo, 2013.

19. Mazcorro-Velarde E, Trueta-Santiago R. La organización como mecanismo para la continuidad del crecimiento porcícola en México. Estudio de caso: Yucatán y Guanajuato. Artículos y Ensayos de Sociología Rural. 2009; 7:9-34. 
